\author{
赤澤 輝和 ${ }^{1,2)}$, 野末よし子 ${ }^{2)}$, 井村 千鶴 ${ }^{2)}$, 森田 達也 ${ }^{2,3)}$ \\ 1) 聖隷三方原病院 医療相談室, 2) 同 浜松がんサポートセンター,3) 同 緩和支持治療科 \\ 受付日 2010 年 8 月 13 日/受理日 2010 年 10 月 15 日
}

\begin{abstract}
緩和ケアの啓発介入として, 地域に一斉配布したリーフレット・冊子・ポスター (啓発用資料) の配布後の実態を明らかに することを目的とした. 啓発用資料を行政施設 104 力所, 図書館 21 力所, 医療福祉施設 132 力所の合計 257 力所に送付 した. 送付後 216 力所 $(84 \%)$ に訪問し，133 カ所 $(62 \%)$ より調査同意を得た. 啓発用資料のいずれかが設置されていた施 設は, 行政施設 55\%, 図書館 100\%, 医療福祉施設 53\%であった. ヒアリングでは, 【目的を理解して設置することの重要 性】配布場所に啓発の対象者がいないことがある】などの7つのテーマが抽出された. 緩和ケアの啓発介入として地域への 啓発用資料の一斉配布は, 設置を目的とした場合, ある程度有効である. 効率良く情報を提供するためには, 設置場所管理者 に目的を伝えることや対象者がいるか把握することなどが有用である可能性が示唆された.

Palliat Car Res 2010; 5(2): 171-174
\end{abstract}

Key words: 緩和ケア, 啓発, 地域

\section{緒 言}

緩和ケアは,病院に設置される緩和ケア病棟や緩和ケアチー ムを超えて, 地域全体への普及が求められている ${ }^{1)}$.しかし, 一 般市民や患者は必ずしも適切な知識を持っていないことが 複数の調查研究で明らかにされている ${ }^{2-5)}$. 緩和ケアに対する 詋った認識は, 適切な緩和ケアや鎮痛治療を阻害する要因と なっており ${ }^{6,7)}$, 緩和ケアに対する正しい知識の普及は重要で ある。

わが国における緩和ケアの啓発介入としては, オレンジバ ルーンプロジェクト ${ }^{8)}$, 国立がん研究センター発行の冊子によ る情報提供 ${ }^{9}$, 講演会による一般市民の認識の推移に関寸る研 究 ${ }^{10)}$ などが行われている. その中でも啓発用資料の配布は最 も一般的な啓発介入であると考えられ,配布された啓発用資料 がどのように利用されるかを把握することは, 有効な啓発介入 を考えるうえで有用な可能性がある.しかし，これまでに，緩 和ケアに関して実際に配布した冊子やポスターがどのように 設置されているかを調査した大規模な報告はない.

本研究の目的は, 緩和ケアの啓発介入として地域に一斉配布 された啓発用資料の配布後の実態を明らかにすることである.

\section{方 法}

本研究は, 第 3 次対がん総合戦略研究事業がん対策のための 戦略研究「緩和ケア普及のための地域プロジェクト」(OPTIM) の一部である ${ }^{1)}$. OPTIM では, 市民, 患者への緩和ケアの知識 の普及を目的として, 緩和ケアに関するリーフレット(『つら い時期を上手に過ごす』A4; 3 つ折り, 設置用の卓上型プラス チックケース付き), 冊子 (『あなたの地域の緩和ケア』, A5; 21 ページ, 設置用の卓上型プラスチックケース付き), 緩和ケアに 関するポスター (サイズは A2 と A 3,4 種類) を作成した ${ }^{11)}$.

\section{1 対 象}

啓発用資料は, 行政施設 104 力所(公民館・自治センター・ 文化センター 55 力所, 市役所・保健所 - 区役所 49 力所), 図書 館 21 力所, 医療福祉施設 132 力所 (病院 12 力所, 診療所 29 力 所, 訪問看護ステーション 12 カ所, 居宅介護支援事業所 19 力 所, 地域包括支援センター 17 力所, 保険薬局 39 力所, 施設 - 教 会なじ 4 力所) の合計 257 施設に配布した. 行政施設は市担当 部署を通じて配布した. 図書館は OPTIMの『緩和ケアを知る 100 冊』を設置, 医療福祉施設は OPTIM 参加・協力施設を対 象として直接郵送した。

\section{2 方 法}

郵送後, 9-13 カ月後に各施設に個別訪問を行い, 配布後の 現況を調查した. 調查は, OPTIMの概要に関する教育を受けた 看護師 1 名が行った. 訪問時, 調査趣旨を説明し, 口頭にて了解 が得られた場合には施設職員の立ち会いのもと, 設置状況の写 真撮影とヒアリングを行った. ヒアリングの内容は, (1)リーフ レット・冊子・ポスターの設置有無, (2)設置後訪問者は見てい るかどうか, (3)情報を見てもらうために工夫・改善した方がい いことについて 30 分程度の質問を行い, メモに記録した. 録音 は行わなかった。

\section{3 解 析}

量的データは度数分布を集計した. 質的データについては, 2 名の研究者 (医療ソーシャルワーカーと看護師) が啓発用資料 の設置状況や利用状況などに影響する要因を抽出し, 緩和ケア 医師 1 名のスーパービジョンのもと, 内容分析を行った.

OPTIM 全体の研究計画は倫理委員会の承認を得, 本研究は 対象施設の自由意思に基づいて匿名性に配慮して行った。 
表 1 リーフレット・冊子・ポスターが設置されていた施設

\begin{tabular}{|c|c|c|c|c|c|}
\hline 調査対象施設 & 施設数 ${ }^{*}$ & リーフレット & 冊子 & ポスター & いずれか \\
\hline 行政施設 & 81 & $45(55 \%)$ & $2(2.5 \%)$ & $34(42 \%)$ & $45(55 \%)$ \\
\hline 公民館・自治センター・文化センター & 37 & $24(65 \%)$ & $2(5.4 \%)$ & $15(41 \%)$ & $25(68 \%)$ \\
\hline 市役所・保健所・区役所 & 44 & $21(48 \%)$ & $0(0 \%)$ & $19(43 \%)$ & $20(45 \%)$ \\
\hline 圈書館 & 18 & $18(100 \%)$ & $18(100 \%)$ & $15(83 \%)$ & $18(100 \%)$ \\
\hline 医療福祉施設 & 117 & $38(32 \%)$ & $33(28 \%)$ & $58(50 \%)$ & $62(53 \%)$ \\
\hline 病院 & 8 & $7(88 \%)$ & $7(88 \%)$ & $7(88 \%)$ & $7(88 \%)$ \\
\hline 診療所 & 28 & $7(25 \%)$ & $4(14 \%)$ & $13(46 \%)$ & $14(50 \%)$ \\
\hline 訪問看護ステーション & 11 & $4(36 \%)$ & $3(27 \%)$ & $7(64 \%)$ & $8(73 \%)$ \\
\hline 居宅介護支援事業所 & 15 & $1(6.7 \%)$ & $0(0 \%)$ & $4(27 \%)$ & $4(27 \%)$ \\
\hline 地域包括支援センター & 13 & $10(77 \%)$ & $11(85 \%)$ & $9(69 \%)$ & $10(77 \%)$ \\
\hline 保険薬局 & 39 & $9(23 \%)$ & $8(21 \%)$ & $17(44 \%)$ & $18(46 \%)$ \\
\hline 施設など & 3 & $0(0 \%)$ & $0(0 \%)$ & $1(33 \%)$ & $1(33 \%)$ \\
\hline 全体 & 216 & $102(47 \%)$ & 53 (25\%) & 107 (50\%) & 125 (58\%) \\
\hline
\end{tabular}

*訪問調査を実施した施設数

\section{結 果}

啓発用資料を一斉配布した 257 施設のうち, 216 施設 (84\%) に訪問した，そのうち 133 施設 $(62 \%)$ より写真撮影とヒアリ ングの同意が得られた。

\section{1 設置状況}

啓発用資料のいずれかが設置されていた施設は, 全体 58\%, 行政施設 $55 \%$, 図書館 $100 \%$, 医療福祉施設 53\%であった (表 1). 設置率が $65 \%$ 以上の施設は, 公民館・自治センター・文化 センター, 図書館, 病院, 訪問看護ステーション, 地域包括支援 センターであった. ポスターとリーフレットの設置率は 47ー $50 \%$ であったが, 冊子は $25 \%$ であった.

2 ヒアリング

内容分析では, 以下の 7 つのテマが抽出された.

\section{1. 目的を理解して設置することの重要性}

行政施設ではリーフレットやポスターについて,「よく分か

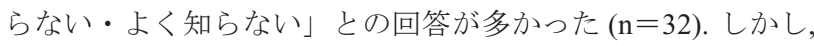
訪問調査で趣旨を説明したところ, 次回から意欲的に取り組み たいとの回答があり,目的を理解して設置を依頼することの重 要性が述べられた $(n=7)$. ある担当者は,「(なんのポスターか よく知らなかったが), こういう良いことはみんなに知らせた い.今度のものが来たら今までより積極的に進めたい」と述べ た.

\section{2. 配布場所に啓発の対象者がいないことがある}

行政施設, 訪問看護ステーション, 居宅介護支援事務所, 地域 包括支援センターでは, 該当する対象者が訪問しないという回 答が多かった $(\mathrm{n}=18)$. たとえば,「ここはほとんど人の出入り がないので申し訳ない」妊婦教室や赤ちゃん関係の催しが中 心で関心のある人は少なそう」などと述べた.一方, 病院, 診療 所, 保険薬局, 図書館では,「関心のある人が見てくれている」 との回答が多かった $(\mathrm{n}=34)$.

\section{3. 配布後工夫をする}

複数の回答者が市民や患者に伝えるために設置方法の工夫 をしていると述べた $(\mathrm{n}=17)$. たとえば, 待合室や駐車場などよ く見てもらえるところに設置する, 隣接している病院や医院な どほかの施設に設置する, 空に外に向けて貼る, ポスターが暗
い感じだったのでディスプレイを工夫する, 医療に関連したポ スターの並びに貼るなどが挙げられた. 特に, 図書館では, 「緩 和」のシールを張る, 医療コーナーに置く, 明るいイラストを つけるなどのさまざまな工夫がなされていた。

4. 配布物が多すぎる・知らないうちになくなっている

行政施設や診療所, 保険薬局では, ポスターや冊子などは送 られてくるものが多すぎるという回答が寄せられた $(n=3)$. ある公民館の職員は,「ポスターやパンフレットはとにかく多 すぎて (内容にかかわらず) 貼れない. 内容も吟味する時間が ない」と述べた. また, 複数の回答者が「知らないうちになく なっていた」と述べられ, 補充をした場合もあるが, 特に補充 などの手続きはしないこともあった $(\mathrm{n}=3)$.

\section{5. 対象者がいなくてもスタッフが見て勉強する}

訪問看護ステーション, 居宅介護支援事業所, 地域包括支援 センター, 保険薬局など対象者が少ない施設では「職員が勉強 している」という回答が多かった $(\mathrm{n}=17)$. たとえば, ある看護 師は,「対象者は少ないけど, スタッフがとても勉強させていた だいています.患者や家族への説明に役立つ」「ホスピスは死ぬ ところと思っていたが印象が良くなった. 最期の時を充実させ て生きるところということが分かり, みんなに知らせたくなっ た」などと述べた.

6. 患者からのフィードバック

がん患者をみている施設では患者に個別に渡していると回 答し $(n=12)$, ある地域包括支援センターでは「がん患者が多 いので, 訪問で積極的に配っており役に立っている」「渡そうと 思ったら他の施設からもうもらっていた」などと述べた。一 方, 保険薬局では,「緩和ケアの話はデリケートで薬局では話を しにくい」など緩和ケアの話をすることが難しいとの回答が あった $(\mathrm{n}=2)$. 多くの施設では,「患者がどういう印象を持って いるかは分からない」と回答したが，「患者から『こういうの があれば良かったのに』と言われたことがある」ここななが あるのねといって声をかけてくれた人がいる」「患者に本を貸 し出したらとても役に立ったと言われた」というような患者 自身からの声を聞いたとの回答があった。

\section{7. ポスターの内容}

ポスターの内容が, 暗い, 冷たい感じがする, 字が小さいた め, もつと字を大きい暖かいものにした方が良いとの回答が複 数あった $(\mathrm{n}=9)$. 


\section{考 察}

本研究は, 市民や患者を対象として, 地域単位で緩和ケアに 関する啓発用資料の一斉配布後の現況を調查した初めての研 究である.

本研究の知見の重要な点の 1 つは, 一斉配布された啓発用資 料の設置頻度を明らかにしたことである. 啓発用資料のいずれ かが設置されていたのは $58 \%$ であった. ヒアリングでは,これ らの施設では配布物が多すぎることや啓発対象者が設置場所 に訪問しないことが示唆された.したがって, 設置を目的とし た場合, 一斎配布は有効な方法の 1 つであるが, 配布前に設置 する目的を管理者に伝え, 合致する啓発対象者がいるかどうか を把握することにより,より有効に設置することができると考 えられる. また, 配布後, 設置場所ではいろいろな工夫が行われ ており,「知らないうちになくなっている」こともあったため, 設置方法の工夫の共有やフィードバックなどフォローアップ を行うことで有効な設置を行うことができる可能性がある. 設 置場所としては, 設置率の高さと対象者の多さという点で, 公 民館・自治センター・文化センター, 図書館, 病院が重要な設 置場所であることが示唆された.

もう 1 つの重要な点は, 啓発対象となる市民や患者がいない 場所であっても, 施設の職員が啓発用資料を読んだり見たりす ることで「勉強になる」との回答が多かった点である. 市民 や患者を対象とした調查から,「最も信頼する情報源」は医師 や看護師などの医療従事者であることが示されている ${ }^{4}$. また， 医療従事者が緩和ケアに対寸る否定的な認識を有しているこ とが示唆されている ${ }^{12}$. このことから, 市民や患者への啓発と いった場合, 対象を市民や患者そのものに設定することと並ん で, 医療従事者へ同じ啓発介入を行うことにも意義があると考 えられた。

本研究の限界として, 啓発用資料の設置状況を調査したも のであり，市民や患者の緩和ケアに関する知識の向上につな がったかは明らかではない. 市民や患者への効果については, OPTIMの介入後調査を待つ必要がある.

\section{結 語}

緩和ケアの啓発介入として地域に一斉配布された啓発用資 料の配布後の実態を検討した. その結果, 啓発用資料は, 一斉配 布することにより半数の行政施設, 医療福祉施設で設置され, 公民館・自治センター・文化センター, 図書館, 病院で設置さ れやすいことが明らかになった.また, 【目的を理解して設置す ることの重要性】【配布場所に啓発の対象者がいないことがあ る】配布後工夫をする】対象者がいなくてもスタッフが見て 勉強する】といった現象がみられた。

本結果から, 設置を目的とした場合, 市民や患者に対する緩 和ケアの啓発介入として地域一の啓発用資料の一斉配布はあ る程度有効であるが, より有効に設置するためには設置場所の 管理者に目的を伝えることや啓発対象者がいるか把握するこ と, 配布後のフィードバックなどが有用である可能性が示唆さ れた。

謝辞 本研究実施にあたり, 多大なご協力を賜りました倉田 園子氏に深謝いたします. 本研究は, 厚生労働科学研究費補助
金第 3 次対がん総合戦略研究事業がん対策のための戦略研究 「緩和ケア普及のための地域プロジェクト」によって行われた.

付記 本調査で撮影された啓発用資料の設置状態については, ホームページで公開されている〔http://www.gankanwa.jp/ region/hamamatsu/pdf/materials_07.pdf].

\section{文 献}

1) Yamagishi A, Morita T, Miyashita M, et al. Palliative care in Japan: current status and a nationwide challenge to improve palliative care by the Cancer Control Act and the Outreach Palliative Care Trial of Integrated Regional Model (OPTIM) study. Am J Hosp Palliat Care 2008; 25:412-418.

2) Morita T, Miyashita M, Shibagaki M, et al. Knowledge and beliefs about end-of-life care and the effects of specialized palliative care: a population-based survey in Japan. J Pain Symptom Manage 2006; 31: 306-316.

3) Sanjo M, Miyashita M, Morita T, et al. Perceptions of specialized inpatient palliative care: a population-based survey in Japan. J Pain Symptom Manage 2008; 35: 275-282.

4) 第 3 次対がん総合戦略研究事業 がん対策のための戦略 研究 緩和ケア普及のための地域プロジェクト: 対象地域 に対する予備調調查. 〔http://gankanwa.jp/tools/pro/survey. $\mathrm{html}]$

5) 日本ホスピス・緩和ケア研究振興財団: ホスピス・緩和ケ アに関する意識調査. 日本ホスピス・緩和ケア研究振興財 団, 2008

6) Morita T, Akechi T, Ikenaga M, et al. Late referrals to specialized palliative care service in Japan. J Clin Oncol 2005; 23 : 2637-2644.

7) Reid CM, Gooberman-Hill R, Hanks GW: Opioid analgesics for cancer pain: symptom control for the living or comfort for the dying? A qualitative study to investigate the factors influencing the decision to accept morphine for pain caused by cancer. Ann Oncol 2008; 19: 44-48.

8) 川崎優子, 内布敦子. がん患者を含めた国民に対する緩和 ケアの普及啓発を目的としたオレンジバルーンプロジェ クトについて. 緩和医療学 2009; 11: 45-50.

9) 国立がん研究センターがん対策情報センターがん情 報サービス：がん対策情報センター発行の冊子.〔http:// ganjoho.jp/public/qa_links/brochure/index.html]

10) Miyashita M, Sato K, Morita T, et al. Effect of a populationbased educational intervention focusing on end-of-life home care, life-prolonging treatment and knowledge about palliative care. Palliat Med 2008; 22: 376-382.

11) 第 3 次対がん総合戦略研究事業がん対策のための戦略研 究 緩和ケア普及のための地域プロジェクト：一般のかた 向けツール・資料.〔http://gankanwa.jp/tools/public/index. html]

12) Fadul N, ElsayemA, Palmer JL,et al. Supportive versus palliative care: What's in a name?: a survey of medical oncologists and midlevel providers at a comprehensive cancer center. Cancer 2009; 115: 2013-2021. 


\title{
A field survey on educational activities for palliative care for citizens and patients
}

\author{
Terukazu Akazawa, ${ }^{1,2)}$ Yoshiko Nozue ${ }^{2)}$, Chizuru Imura ${ }^{2)}$ and Tatsuya Morita, ${ }^{2,3}$
}

1) Section of Social Work, Seirei Mikatahara General Hospital, 2) Hamamatsu Cancer Support Center, ditto,

3) Department of Palliative and Supportive Care, ditto

\begin{abstract}
Purpose: Improving knowledge of palliative care among cancer patients and the general public may be useful for achieving a better quality of life for cancer patients. The aim of this study was to identify the actual situation after the dissemination of leaflets, booklets, and posters as a part of a regional palliative care program. Methods: We distributed leaflets, booklets, and posters on palliative care to 257 administrative and health institutions across the region. We also visited 216 institutions (84\%) to observe the actual situation and performed interviews in 133 of the institutions $(62 \%)$. Results: Overall, $58 \%$ of the institutions used the leaflets, booklets or posters. Public halls, libraries and hospitals used them at a rate of $65 \%$ or higher. Interviews identified 7 themes, including "explaining the aim of the project before dissemination is important", "few cancer patients or even the general public visit", "staff made various efforts to display the items after dissemination", and "staff learned from the leaflets and booklets, even if cancer patients seldom visited". Conclusion: The dissemination of leaflets, booklets or posters throughout the region might be useful for conveying accurate knowledge about palliative care not only for cancer patients and the general public, but also for health care professionals. Target institutions should include public halls, libraries, and hospitals, and pre-dissemination discussions about the aim of the project and what kinds of people visit the institutions in addition to post-dissemination follow-up may be useful.
\end{abstract}

Palliat Care Res 2010;5(2): 171-174

Key words: palliative care, education, community

Table 1 Facilities where information leaflets, booklets and posters were placed

\begin{tabular}{|c|c|c|c|c|c|}
\hline Institutions & $\begin{array}{c}\text { Number of } \\
\text { institutions * }\end{array}$ & Leaflets & Booklets & Posters & $\begin{array}{l}\text { Leaflets, } \\
\text { booklets } \\
\text { or posters }\end{array}$ \\
\hline Administration institutions & 81 & $45(55 \%)$ & $2(2.5 \%)$ & $34(42 \%)$ & $45(55 \%)$ \\
\hline Public hall, Self-government center, Cultural center & 37 & $24(65 \%)$ & $2(5.4 \%)$ & $15(41 \%)$ & $25(68 \%)$ \\
\hline City office, Health care center, Ward office & 44 & $21(48 \%)$ & $0(0 \%)$ & $19(43 \%)$ & $20(45 \%)$ \\
\hline Libraries & 18 & $18(100 \%)$ & $18(100 \%)$ & $15(83 \%)$ & $18(100 \%)$ \\
\hline Health care institutions & 117 & $38(32 \%)$ & $33(28 \%)$ & $58(50 \%)$ & $62(53 \%)$ \\
\hline Hospitals & 8 & $7(88 \%)$ & $7(88 \%)$ & $7(88 \%)$ & $7(88 \%)$ \\
\hline Clinic & 28 & $7(25 \%)$ & $4(14 \%)$ & $13(46 \%)$ & $14(50 \%)$ \\
\hline Home-visit nursing station & 11 & $4(36 \%)$ & $3(27 \%)$ & $7(64 \%)$ & $8(73 \%)$ \\
\hline Home care support office & 15 & $1(6.7 \%)$ & $0(0 \%)$ & $4(27 \%)$ & $4(27 \%)$ \\
\hline Community general support center & 13 & $10(77 \%)$ & $11(85 \%)$ & $9(69 \%)$ & $10(77 \%)$ \\
\hline Community pharmacy & 39 & $9(23 \%)$ & $8(21 \%)$ & $17(44 \%)$ & $18(46 \%)$ \\
\hline Others & 3 & $0(0 \%)$ & $0(0 \%)$ & $1(33 \%)$ & $1(33 \%)$ \\
\hline Overall & 216 & $102(47 \%)$ & $53(25 \%)$ & $107(50 \%)$ & $125(58 \%)$ \\
\hline
\end{tabular}

* number of facilities visited 